\title{
Lactate Dehydrogenase Isoenzymes in Dental Pulp of Rats According to Stage of Root Development
}

\author{
Estela Maris LOSSO \\ José NICOLAU ${ }^{2}$ \\ ${ }^{1}$ Stomatology Department, Federal University of Paraná, Curitiba, PR, Brazil \\ ${ }^{2}$ Oral Biology Research Center, Faculty of Dentistry, University of São Paulo, São Paulo, SP, Brazil
}

\begin{abstract}
The objective of this study was to present a classification of the root development stage of female rat molar teeth and to evaluate the variation in the lactate dehydrogenase (LDH) activity and electrophoretic isoenzyme profile according to the stage of root development of the molar teeth. We also studied the LDH activity and isoenzymes of the pulp of incisor teeth. The stage of development of the rat first molar at the age of 15 days and that of the second molar at the age of 18 days was classified as the beginning of root formation. At the age of 15 days, the electrophoretic profile of the isoenzymes for the first molar showed a prevalence of LDH-1 followed by LDH2. However, for the maxillary second molar there was a prevalence of LDH-4 followed by LDH-1, while for the mandibular second molar LDH-1 predominated followed by LDH-2 and LDH-4. From 18 days of age, the prevalence was always of LDH-1. The electrophoretic profile of LDH isoenzymes from the pulp of the incisor teeth at the ages studied (25 and 60 days) showed the following order of prevalence: LDH-1 > LDH-2 > LDH-3 > LDH-4 > LDH-5. These results suggest that there are variations in the prevalence of the various forms of $\mathrm{LDH}$ isoenzymes in the dental pulp of rats according to the developmental stage of the root.
\end{abstract}

Key Words: dental pulp, isoenzymes, lactate dehydrogenase, rat.

\section{INTRODUCTION}

The interconversions of pyruvate and lactate in tissues depend on the catalytic properties of the enzyme lactate dehydrogenase (LDH). Investigators commonly study LDH in dental pulp by histochemical or biochemical procedures to evaluate the effect of dental products normally used in dental practice (1-4). This enzyme is a tetramer with two kinds of $35 \mathrm{Kd}$ subunits, which associate to form five species of tetramers called isoenzymes (LDH-1, LDH-2, LDH-3, LDH-4 and LDH5). The distribution pattern of the isoenzymes reflects the tendency of a tissue to anaerobic or aerobic metabolism.

The presence of LDH isoenzymes in dental pulp has been reported by many investigators, with the prevalence of LDH-1 and LDH-2 in the pulp of incisor teeth of mice $(5,6)$ and the prevalence of LDH-3 followed by LDH- 2 and LDH-4 in the pulp of deciduous and permanent teeth $(7,8)$. On the other hand, an increase in LDH-4 and LDH-5 activity has been observed in injured dental pulps (8). These data partially coincide with those reported for electrophoretic separation of normal and inflamed permanent dental pulps (9), where the prevalence of the isoenzymes was about the same and LDH-5 was only detected in the inflamed pulps. The presence of three isoenzymes, LDH-1, LDH-2 and LDH-3, has been demonstrated in the pulp of the first permanent teeth (10). In pulps of porcine deciduous teeth, the activity of LDH was higher for root formation and root resorption than for the fully formed root (11). A comparison of the electrophoretic profiles of $\mathrm{LDH}$ isoenzymes during the vital cycle of the porcine deciduous teeth demonstrated the presence of the five isoenzymes with the prevalence of LDH-1 and LDH-2 and a relative increase of $\mathrm{LDH}-5$ in the root resorption phase (12)

The objective of this study was to present a classification of the root development stage of female rat molar teeth and to evaluate the variation in the lactate dehydrogenase (LDH) activity and electrophoretic isoenzyme profile according to the stage of root development of the molar teeth. We also studied the LDH activity and isoenzymes of the pulp of the incisor teeth. 


\section{MATERIAL AND METHODS}

Female Wistar rats of various ages were used in the present investigation. The dental pulps of the incisors were analyzed in rats aged 25 and 60 days. For the analysis of the molar dental pulps during the various phases of root development, animals aged 15, 18, 21, $25,30,40,60$, and 90 days were used. The stage of root development of molars was determined using a stereoscopic microscope.

The animals, aged 25 to 90 days, were weaned at 21 days of age and maintained in cages with free access to water and food. Sacrifice was performed by cranial traumatism always in the morning (8:15-9:00). After sacrifice, the jaw and maxilla were removed and the teeth extracted. Due to their small degree of development, the third molars were used only for animals aged 30 days or older The pulp sample from incisors consisted of a pool of pulps from several teeth.

Immediately after extraction, the teeth were dried on filter paper, weighed and homogenized at $10 \%$ in a Potter-Elvehjem type homogenizer with $50 \mathrm{mM}$ imidazole buffer, $\mathrm{pH}$ 7.0, containing $2 \mathrm{mM}$ EDTA and $1 \mathrm{mM}$ mercaptoethanol. The homogenate was centrifuged at $12,300 \mathrm{~g}$ for $20 \mathrm{~min}$ in a refrigerated centrifuge and the supernatant was used for analysis. LDH activity was assayed by the method of Bergmeyer and Bernt (13) and protein was determined by the method of Lowry et al. (14) using bovine serum albumin (Sigma, St. Louis, MO) as standard. The LDH isoenzymes were separated by disk electrophoresis by the method of Davis (15) modified by Dietz and Lubrano (16) on 5.5\% polyacrylamide gel in glass tubes $(0.6 \times 8.1 \mathrm{~cm})$ at $4^{\circ} \mathrm{C}, 2.5 \mathrm{~mA}$ per tube. After the electrophoretic run, the gels were incubated in $0.5 \mathrm{M}$ phosphate buffer, $\mathrm{pH} 7.4$, for $5 \mathrm{~min}$. The isoenzymes were identified by incubating the gels in $0.5 \mathrm{M}$ phosphate buffer, $\mathrm{pH} 7.4$, containing $1 \mathrm{mM}$ lithium lactate, $10 \mathrm{mg} / \mathrm{ml} \mathrm{NAD}, 0.1 \mathrm{M} \mathrm{NaCl}, 5 \mathrm{mM}$ $\mathrm{MgCl}_{2}, 1 \mathrm{mg} / \mathrm{ml}$ nitroblue tetrazolium and $1 \mathrm{mg} / \mathrm{ml}$ phenazine methosulfate. After incubation, the gels were fixed and stored in $7 \%$ acetic acid. The gels were then submitted to densitometric analysis in a Gilford 2400 spectrophotometer.

For the statistical analysis, the data are presented as mean \pm SD. The Student " $t$ " test was used to determine differences between the means for each group and the reference, established for the animals with fully formed roots (90 days old).

\section{RESULTS}

Table 1 shows the root development phases of the molar teeth of female Wistar rats at different ages. The first and second molar teeth of the animals at 15 days of age and the third molar teeth at 18 days of age can be classified into a developmental stage that belongs just to the beginning of root formation. Table 2 shows the results obtained for LDH activity. Since at 90 days of age all molars presented a fully formed root, the animal group of this age was considered as the reference for the statistical analysis.

The activity of the enzyme in the pulp from the

Table 1. Classification of root developmental stage of the molar teeth from female Wistar rats of different ages.

\begin{tabular}{|c|c|c|c|c|c|c|}
\hline \multirow{2}{*}{$\begin{array}{l}\text { Age } \\
\text { (days) }\end{array}$} & \multicolumn{2}{|c|}{$1^{\text {st }}$ molar } & \multicolumn{2}{|c|}{$2^{\text {nd }}$ molar } & \multicolumn{2}{|c|}{$3^{\text {rd }}$ molar } \\
\hline & Maxillary & Mandibular & Maxillary & Mandibular & Maxillary & Mandibular \\
\hline 15 & $\mathrm{BRF}^{*}$ & $\mathrm{BRF}^{*}$ & $\mathrm{CC}^{*}$ & $\mathrm{CC}^{*}$ & CBM* & $\mathrm{CBM}^{*}$ \\
\hline 18 & $\pm 1 / 3$ FR & $\pm 1 / 3 \mathrm{FR}$ & $\mathrm{BRF}^{*}$ & BRF* & $\pm 1 / 3 \mathrm{FC}^{*}$ & $\pm 1 / 2-2 / 3 \mathrm{FC}^{*}$ \\
\hline 21 & 1/3-1/2 FR & 1/3-1/2 FR & 1/3-1/2 FR & 1/3 FR & 2/3 FC* & $2 / 3 \mathrm{FC}^{*}$ \\
\hline 25 & $1 / 2 \mathrm{FR}$ & $1 / 2 \mathrm{FR}$ & $1 / 3-1 / 2 \mathrm{FR}$ & 1/3-1/2 FR & $\mathrm{CAC}^{*}$ & $\mathrm{CAC}^{*}$ \\
\hline 30 & 1/2-2/3 FR & 2/3 FR & 1/2 FR & $1 / 2 \mathrm{FR}$ & $\mathrm{CC}^{*}$ & $\mathrm{CC}$ \\
\hline 40 & AFR & AFR & 2/3 FR & 2/3 FR & $1 / 2-2 / 3 \mathrm{FR}$ & 2/3 FR \\
\hline 50 & $\mathrm{CR}$ & $\mathrm{CR}$ & $\mathrm{CR}$ & $\mathrm{CR}$ & AFR & AFR \\
\hline $60-90$ & $\mathrm{CR}$ & $\mathrm{CR}$ & $\mathrm{CR}$ & $\mathrm{CR}$ & $\mathrm{CR}$ & $\mathrm{CR}$ \\
\hline
\end{tabular}

AFR: almost formed root; BRF: beginning of root formation; CBM: crown at the beginning of mineralization; CAC: crown almost complete; CC: complete crown; CR: complete root; FC: formed crown; FR: formed root. * Unerupted tooth. 
incisor teeth, which are active dentinogenesis teeth, presented a specific activity of $2.066 \pm 0.416 \mathrm{U} / \mathrm{mg}$ protein. Figure 1 shows the electrophoretic profile of LDH isoenzymes in the molar pulp of rats aged 15 to 30 days, and Figure 2 shows the profile from animals aged 40 to 90 days, and those of the pulp of incisor teeth from 25- and 60-day-old animals. All five LDH isoenzymes were detected in the pulp of molar and incisor teeth from female rats. It is possible to see the prevalence of the forms related to aerobic metabolism (LDH-1 and LDH-2) in the pulp of molar teeth. At 15 days of age, when the root is just starting to form (Table 1), the bands corresponding to LDH-4 and LDH-5 are more evident.

\section{DISCUSSION}

The results presented in this investigation clearly show that there are variations in the prevalence of the various forms of LDH isoenzymes in the dental pulp of rats according to the developmental stage of the root. Considering the pulp from the first and second molar teeth in animals aged 15 and 18 days, there was a prevalence of the species of isoenzymes linked to both aerobic (LDH-1 and LDH-2) and anaerobic metabolism (LDH-4 and LDH-5). This finding suggests that at this stage of root development both types of metabolism (aerobic and anaerobic) are equally important. During root formation when the need for energy is important, there was a predominance of the LDH-1 and LDH-2 forms, related to aerobic metabolism. This pattern of variation was observed in the pulp of the third molar teeth at the age of 40 and 50 days. In fact, the relative activity of different pathways of the carbohydrate metabolism in deciduous pulp in the development of porcine molars, assessed by the activity of key enzymes, showed that in the root formation and root resorption phases aerobic glycolysis was higher than in fully formed teeth (11). Higher LDH activity and isoenzymes linked to anaerobic metabolism were demonstrated in inflamed human pulp (9) rather than in healthy pulp. Coinciding with weaning at 21 days of age, there was a prevalence of the LDH-1 form, mainly for the mandibular second molar teeth. At the age of 25 days, a reduction in the

Table 2. Specific activity (U/mg protein) of the LDH enzyme in the pulp of molar teeth from female Wistar rats of different ages.

\begin{tabular}{|c|c|c|c|c|c|c|}
\hline \multirow{2}{*}{$\begin{array}{l}\text { Age } \\
\text { (days) }\end{array}$} & \multicolumn{2}{|c|}{$1^{\text {st }}$ molar } & \multicolumn{2}{|c|}{$2^{\text {nd }}$ molar } & \multicolumn{2}{|c|}{$3^{\text {rd }}$ molar } \\
\hline & Maxillary & Mandibular & Maxillary & Mandibular & Maxillary & Mandibular \\
\hline 15 & $\begin{array}{c}1.108 \pm 0.327 * * \\
(10)\end{array}$ & $\begin{array}{c}0.086 \pm 0.287 \\
(7)\end{array}$ & $\begin{array}{c}0.376 \pm 0.128 * \\
(40)\end{array}$ & $\begin{array}{c}0.256 \pm 0.088^{* *} \\
\quad(5)\end{array}$ & - & - \\
\hline 18 & $\begin{array}{c}1.016 \pm 0.282 * * \\
(14)\end{array}$ & $\begin{array}{c}0.807 \pm 0.222 \\
(12)\end{array}$ & $\begin{array}{c}0.420 \pm 0.119 * * \\
(10)\end{array}$ & $\begin{array}{l}0.931 \pm 0.124 * * \\
(6)\end{array}$ & - & - \\
\hline 21 & $\begin{array}{c}0.992 \pm 0.170^{* *} \\
\text { (10) }\end{array}$ & $\begin{array}{c}1.046 \pm 0.234 * * \\
\text { (11) }\end{array}$ & $\begin{array}{c}0.948 \pm 0.256^{*} \\
(7)\end{array}$ & $\begin{array}{c}0.645 \pm 0.142 \\
(6)\end{array}$ & - & - \\
\hline 25 & $\begin{array}{c}0.834 \pm 0.206 \\
(12)\end{array}$ & $\begin{array}{c}0.770 \pm 0.131 \\
(10)\end{array}$ & $0.709 \pm 0.123$ & $\begin{array}{c}0.608 \pm 0.151 \\
(10)\end{array}$ & - & - \\
\hline 30 & $\begin{array}{c}0.806 \pm 0.197^{*} \\
(14)\end{array}$ & $\begin{array}{c}0.784 \pm 0.158 \\
(10)\end{array}$ & $0.687 \pm 0.181$ & $\begin{array}{l}0.898 \pm 0.239 * * \\
\text { (7) }\end{array}$ & $\begin{array}{c}0.461 \pm 0.004 \\
\text { (2) }\end{array}$ & $\begin{array}{c}0.430 \pm 0.141 \\
\text { (2) }\end{array}$ \\
\hline 40 & $\begin{array}{c}1.092 \pm 0.292 * * \\
\text { (12) }\end{array}$ & $\begin{array}{c}1.032 \pm 0.249 * * \\
\text { (9) }\end{array}$ & $\begin{array}{c}0.851 \pm 0.263 \\
(7)\end{array}$ & $\begin{array}{c}0.679 \pm 0.239 \\
\text { (7) }\end{array}$ & $\begin{array}{c}0.843 \pm 0.211^{*} \\
(6)\end{array}$ & $\begin{array}{c}0.629 \pm 0.147 \\
(4)\end{array}$ \\
\hline 50 & $\begin{array}{c}0.781 \pm 0.056 \\
(10)\end{array}$ & $\begin{array}{c}0.808 \pm 0.113 \\
\text { (11) }\end{array}$ & $0.814 \pm 0.094^{+}$ & $\begin{array}{c}0.679 \pm 0.137 \\
\text { (9) }\end{array}$ & $\begin{array}{c}0.768 \pm 0.152 \\
\text { (4) }\end{array}$ & $\begin{array}{c}0.812 \pm 0.034 * * \\
\text { (4) }\end{array}$ \\
\hline 60 & $\begin{array}{c}0.769 \pm 0.168 \\
(12)\end{array}$ & $\begin{array}{c}0.714 \pm 0.190 \\
(11)\end{array}$ & $\begin{array}{c}0.714 \pm 0.093 \\
(8)\end{array}$ & $\begin{array}{c}0.709 \pm 0.125^{*} \\
(10)\end{array}$ & $\begin{array}{c}0.520 \pm 0.094 \\
(4)\end{array}$ & $\begin{array}{c}0.452 \pm 0.126 \\
(6)\end{array}$ \\
\hline 90 & $\begin{array}{c}0.695 \pm 0.170 \\
\text { (11) }\end{array}$ & $\begin{array}{c}0.703 \pm 0.182 \\
(12)\end{array}$ & $\begin{array}{c}0.675 \pm 0.192 \\
(9)\end{array}$ & $\begin{array}{c}0.540 \pm 0.178 \\
\text { (9) }\end{array}$ & $\begin{array}{c}0.543 \pm 0.045 \\
\text { (3) }\end{array}$ & $\begin{array}{c}0.490 \pm 0.162 \\
\text { (4) }\end{array}$ \\
\hline
\end{tabular}

Data are reported as mean $\pm \mathrm{SD}$ for the number of samples indicated in parenthesis. $* \mathrm{p}<0.05$, $* * \mathrm{p}<0.01=$ significant value using the Student " $\mathrm{t}$ " test when compared with the 90 -day age group. ${ }^{+} \mathrm{P}<0.05=$ significant value using the Student " $\mathrm{t}$ " test when comparing the mandibular and maxillary molar at the same age. 


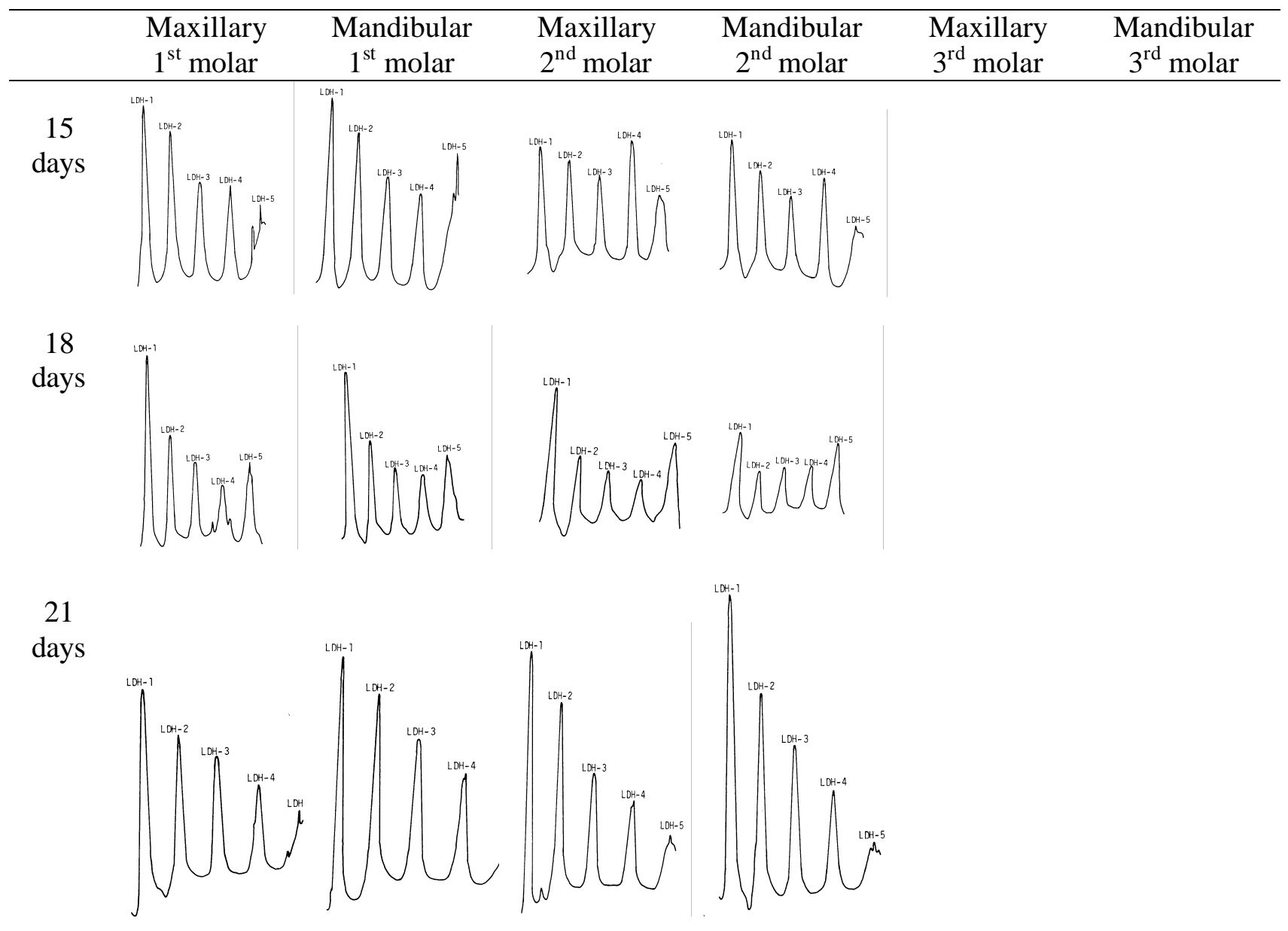

25

days
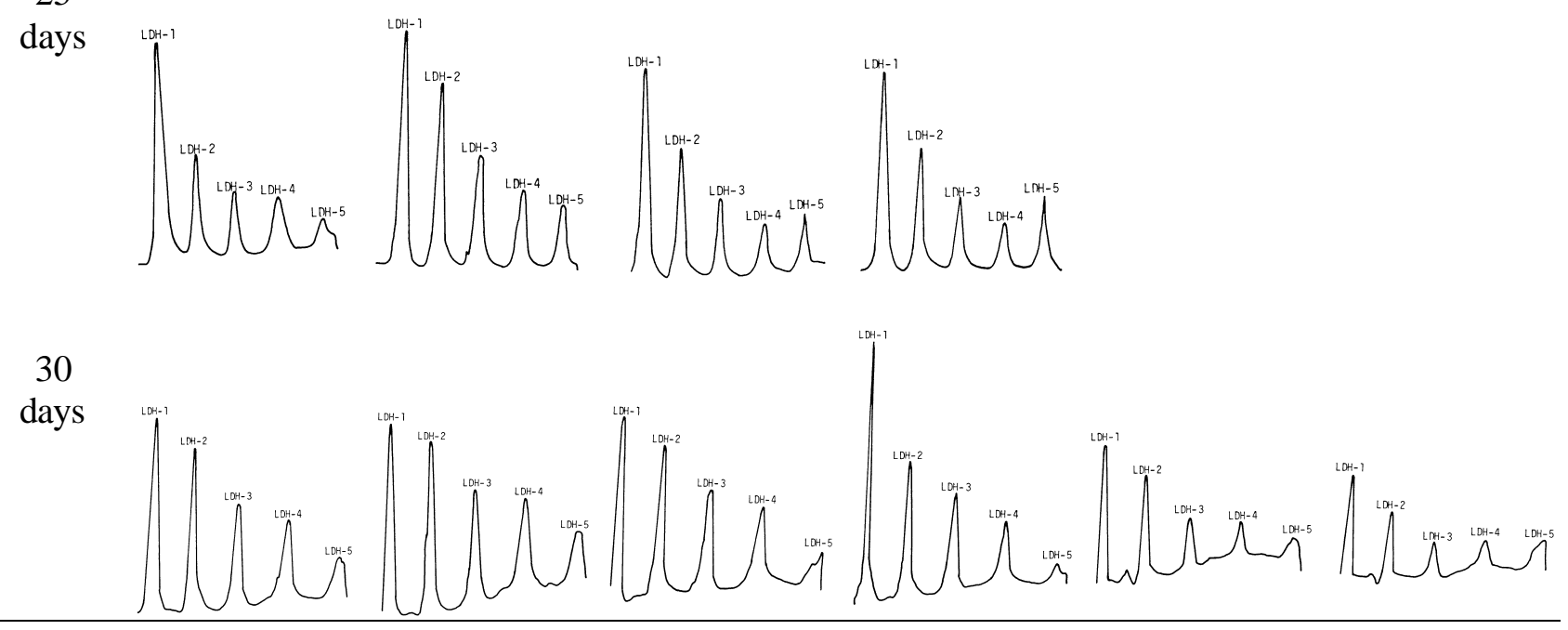

Figure 1. Densitogram of the five LDH isoenzymes detected by disc electrophoresis in the pulp of molar teeth from female Wistar rats aged 15 to 30 days during various phases of root development. 
densitogram was noted in the electrophoretic bands corresponding to all five isoenzymes for all teeth. However, even though all bands were reduced in comparison to the other age groups, there was a prevalence of LDH1 and LDH-2 over the other isoenzymes. The electrophoretic profile of the isoenzymes in the pulp of the third molar teeth showed that at 40 days of age, with $1 / 2$ to $2 / 3$ of the root formed, the prevalence of LDH- 1 was higher in relation to the other age groups for these teeth. The profile of the isoenzyme at the age of 90 days, together with the fact that at this age the root is fully formed, led us to consider this age group as the reference. In this age group, the prevalence of LDH-1 was about the same as that of LDH-2 and neither was high compared to the other forms of isoenzymes, a fact indicating a balance between aerobic and anaerobic metabolism. According to Roberts and Strachan (17), in the pulp of mouse teeth there is a reduction of $\mathrm{LDH}$

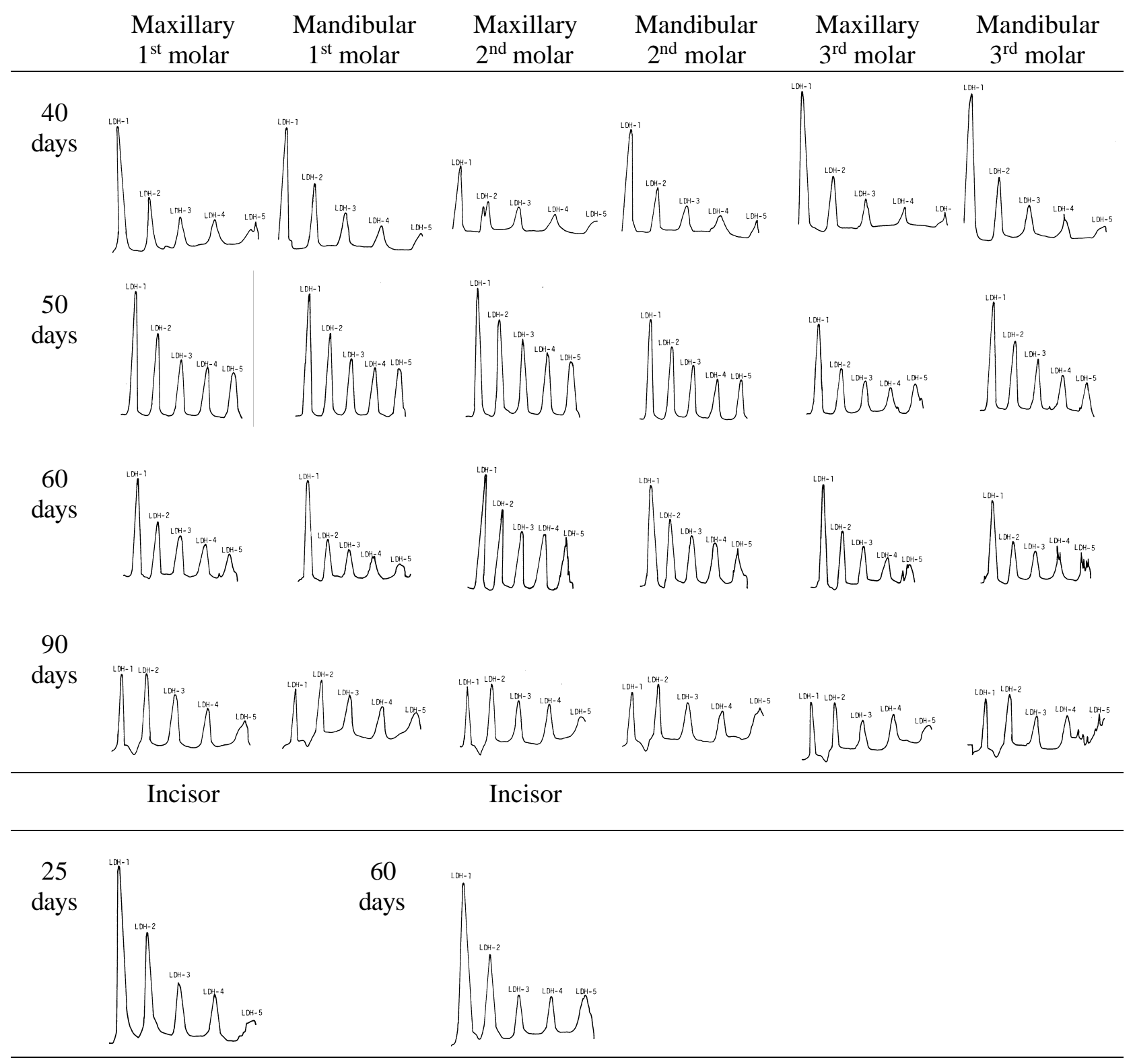

Figure 2. Densitogram of the five LDH isoenzymes detected by disc electrophoresis in the pulp of molar and incisor teeth from female Wistar rats during various phases of root development (animals aged 40 to 90 days for the molar pulp and 25 and 60 days for the incisor pulp). 
activity with age. Concerning the isoenzymes, these investigators reported that the five isoenzymes were present at the beginning but all of them diminished and the bands corresponding to LDH-1 and LDH-2 were not detected. The five isoenzymes have been reported to be present in the pulp of the rat incisor teeth, with a prevalence of LDH-1 and LDH-2 $(5,6)$.

When we compared the specific activity of LDH in the pulp from the incisor $(2.06 \pm 0.42 \mathrm{U} / \mathrm{mg}$ protein $)$ with that in the pulp from the molar teeth, we observed that the value for the incisor pulp was two-fold that for the molar pulp. As the incisor teeth of rodents are in continuous growth, this may be the reason for this difference.

Since molar teeth of rats are used to evaluate the effect of materials on the dental pulp (18-21), knowledge of dental pulp metabolism is very important. However, surprisingly, we did not find this matter in the literature. Thus, the results of the present study add relevant information to future studies related to dental pulp function.

Table 1 describes the stage of root development in female rat molar teeth. Using a stereoscopic microscope, we tried to establish the various phases of root development of the animal age we examined. We had some difficulties in classifying the stage of root development of the third molar teeth in animals aged 15-25 days, and therefore we decided not to examine the samples from these ages. The stage of development of the rat first molar at the age of 15 days and that of the second molar teeth at the age of 18 days indicates that this is the phase when root formation was just beginning. We did not find in the literature a description of the stages of root development of rat molar teeth. Since several studies used rat molar teeth, the table described here will be a reference to the stages of root development.

In conclusion, the results of the present study suggest that there are variations in the prevalence of the various forms of LDH isoenzymes in the dental pulp of rats according to the developmental stage of the root.

\section{ACKNOWLEDGEMENTS}

The authors wish to thank Dr. Roberto Andreatini for his help in the preparation of the manuscript and to Dr. Hidevaldo B. Machado for reviewing the manuscript and for helpful suggestions.

\section{RESUMO}

Os objetivos deste trabalho foram: realizar uma classificação do estágio de desenvolvimento de molares de ratas; determinar a atividade específica da lactato desidrogenase (LDH) e o perfil eletroforético das isoenzimas da LDH de acordo com o estágio de desenvolvimento dos molares. Também foi estudado a atividade específica da LDH e perfil eletroforético das isoenzimas de polpas de incisivos. O estágio de desenvolvimento do primeiro molar de ratas na idade de 15 dias e o segundo molar na idade de 18 dias foi determinado como o início da formação radicular. Aos 15 dias de idade, o perfil eletroforético das isoenzimas mostrou uma prevalência da LDH-1 seguida pela LDH-2. Entretanto o segundo molar superior apresentou uma prevalência da LDH-4 seguida de LDH-1, mas no segundo molar inferior o predomínio foi de LDH-1 seguido de LDH-2 e LDH-4. A partir dos 18 dias de idade a prevalência foi sempre da LDH-1. O perfil eletroforético das isoenzimas da LDH em polpas de incisivos nas idades estudadas (25-60 dias de idade) mostrou uma prevalência de LDH-1 > LDH-2 > LDH-3 > LDH-4 > LDH-5. Portanto, os resultados do presente estudo indicam que existem variações na prevalência das formas de isoenzimas da $\mathrm{LDH}$ de acordo com o estágio de desenvolvimento da raiz.

\section{REFERENCES}

1. Pezzoli M, Baldi P. In vitro evaluation of the cytotoxicity of composite resin in the presence or absence of smear layer. Minerva Stomatol 1997;46:481-486.

2. Hill SD, Seale NS, Quintero EM, Guo IY. The effect of glutaraldehyde pulpotomy treatment on pulpal enzymes. Pediatr Dent 1993;15:337-342.

3. Cunningham KW, Lazzari EP, Ranly DM. The effect of formocresol and glutaraldehyde on certain enzymes of bovine dental pulp. Oral Surg Oral Med Oral Pathol 1982;54:100-103.

4. Engstrom C, Rockert HO. Effects of local anesthetics on aerobic and anaerobic metabolism of the dental pulp. Swed Dent J 1980;4:119-123.

5. Linde A, Ljunggren AE. Lactate dehydrogenase isoenzymes of the rat incisor pulp. Arch Oral Biol 1970;15:65-69.

6. Dobrynina VI, Razin AS, Fridman KE. Lactate dehydrogenase isoenzymes in the dental pulp of rats under normal conditions in thermic burns. Stomatoliya (Mosk) 1974;53:1-3.

7. Linde A, Ljunggren AE. Lactate dehydrogenase isoenzyme patterns of human dental pulp. J Dent Res 1970;49:1469-1472

8. Klimecky J, Kamaryt J. Isoenzymes of lactate dehydrogenase in dental pulp. Cesk Stomatol 1972;72:35-42.

9. Messelt EB, Skogedal O, Eriksen HM. Lactate dehydrogenase (LDH) isoenzyme pattern in normal and inflamed human dental pulp. Acta Odontol Scand 1978;36:345-348.

10. Sato N, Goto H, Hirakavama K. Lactate dehydrogenase isoenzymes in pig dental pulp. Japan J Pedodon 1985;23:13-19.

11. Siquara-da-Rocha MCB, Nicolau J. Metabolic activity of deciduous porcine dental pulp in different phases of root development. J Dent Res 1980;59:762-765.

12. Losso EM, Nicolau J. Variation of the lactate dehydrogenase isoenzymes in porcine deciduous dental pulp during root formation, fully formed root and root resorption. Rev Odont USP 1992;6:7-12.

13. Bergmeyer HU, Bernt E. Lactate dehydrogenase. In: Methods of 
Enzymatic Analysis. Bergmeyer HU ed. 2nd edition, Vol 2. New York: Verlag Chemie; 1974. p 574-579.

14. Lowry OH, Rosebrough NJ, Farr AL, Randall R. Protein measurement with the Folin phenol reagent. J Biol Chem 1951;193:265-275.

15. Davis BJ. Disc electrophoresis. II: Method and application to human serum proteins. Ann NY Acad Sci 1964;121:404-427.

16. Dietz AA, Lubrano T. Separation and quantitation of lactate dehydrogenase isoenzymes by disc electrophoresis. Anal Biochem 1967;20:246-257.

17. Roberts W, Strachan DS. Quantitation of lactate dehydrogenase of developing molar teeth of mouse. J Dent Res 1967;46:522526.
18. Costa CA, Hebling J, Hanks CT. Current status of pulp capping with dentin adhesive systems: a review. Dent Mat 2000;16:188 197.

19. Costa CA, Mesas AN, Hebling J. Pulp response to direct capping with an adhesive system. Am J Dent 2000;13:81-87.

20. Dammaschke T, Stratmann U, Mokrys K, Kaup M, Reiner Ott $\mathrm{KH}$. Reaction of sound and demineralised dentine to Carisolv in vivo and in vitro. J Dent 2002;30:59-65.

21. Leonora J, Tjäderhane L, Tieche JM. Effect of dietary carbamyl phosphate on dentine apposition in rat molars. Arch Oral Biol 2002;47:147-153.

Accepted November 25, 2002 